\title{
Implementasi Prinsip-Prinsip Strukturalisme untuk Mengidentifikasi Kondisi Aktual Dry Leaf Board sebagai Material Perancangan Interior
}

\section{Firman Hawari}

Departemen Desain Interior, FTSP, Institut Teknologi Sepuluh Nopember - Surabaya

firmanhawari@ymail.com

\begin{abstract}
ABSTRAK
Beberapa kajian mengenai dry leaf board yang dilakukan sebelumnya telah memunculkan beberapa asumsi, antara lain: orisinalitas, urban waste, customize, aplikasi manual, dan pemanfaatan dry leaf board itu sendiri. Asumsi-asumsi tersebut menunjukkan bahwa proses penciptaan dan produksi dry leaf board telah melahirkan bentuk dan struktur yang dapat dilihat bahkan dinilai. Secara filosofis, dry leaf board membangun makna berdasarkan pada bentuk dan struktur tersebut yang terkait erat dengan pola pikir masyarakat di mana ia diciptakan.

Kajian berikut ini akan difokuskan pada pembahasan implementasi prinsip-prinsip strukturalisme untuk mengidentifikasi kondisi aktual dry leaf board. Pembahasannya dikaitkan dengan prinsip-prinsip universal dari pikiran manusia yang menjadi dasar karakter budaya dan kebiasaan-kebiasaan yang dilakukan manusia dalam proses penciptaan dan produksi dry leaf board sebagai material perancangan interior. Gagasan strukturalisme juga melakukan pencarian keterpaduan unsur pembangun dari realitas gagasan dry leaf board yang beraneka ragam di permukaan secara ilmiah (obyektif, ketat dan berjarak). Berdasarkan pemahaman strukturalisme, makna aktual dry leaf board tidak bersumber dari individu manusia melainkan lebih memusat pada sistem relasi bentuk yang mendasarinya seperti material, proses produksi, kemampuan fisik, serta hasil akhirnya.

Pemikiran tersebut membuka peluang pembahasan implementasi prinsip-prinsip strukturalisme dalam membangun sistem relasi bentuk dan struktur pada dry leaf board. Terungkapnya gagasan aktual dari dry leaf board diharapkan akan dapat mempengaruhi pengembangan visual dan pemanfaatannya serta pengaruhnya pada perancangan interior ruang secara keseluruhan di masa yang akan datang.

Kata kunci: dry leaf board; strukturalisme; sistem relasi bentuk; kondisi aktual
\end{abstract}

\section{ABSTRACT}

Many research about dry leaf board that has been done previously has concluded some assumptions, among others: originality, urban waste, customize, manual application, and utilization. These assumptions suggest that the process of creating and producing dry leaf boards has produce form and structure that can be seen and even assessed. Philosophically, dry leaf board builds meaning based on the form and structure that is closely related to the mindset of the society in which it was created.

This study will be focused on discussing an implementation of structuralism principles to identify actual condition of dry leaf board. A discussion will be linked to universal principles of human mind that become base on cultural character and man-habits in process of creating and producing dry leaf board as an interior design material. The idea of structuralism also searches for the integration of constructive elements from the reality of dry leaf board ideas that are scientifically diverse (objective, strict and distantly). Based on understanding of structuralism, an actual meaning of dry leaf board does not originate from individual human beings but rather focuses on base forms of relation systems such as material, production processes, physical capabilities, and end result. That thought opens an opportunity for discussing implementation of structuralism principles in building the system of form and structure relationships on dry leaf board. The disclosure of actual idea of dry leaf board is expected to affect visual development and its utilization as well as its influence on design of interior space as a whole in the future. 
Keywords: dry leaf board; strukturalism; system of form relations; actual condition

\section{PENDAHULUAN}

Pada masa awalnya, kajian strukturalisme lebih banyak mengkaji karya sastra, psikologi, dan linguistik sebagai reaksi terhadap evolusionisme positivis dengan menggunakan metodemetode riset struktural yang dihasilkan oleh matematika, fisika, dan ilmu alam lainnya. Terjadi pergeseran dari struktur sosial dan struktur bahasa kemudian strukturalisme diorientasikan untuk memahami struktur-struktur yang mendasari bahasa dalam konteks-konteks yang lebih besar di mana mereka berada dan berkembang. Bahasa dilihat sebagai hasil rancangan dari pemikiran dan tindakan yang membentuk pola universal hingga menghasilkan realitas sosial. Strukturalisme menjadi praktik signifikansi yang membangun makna sebagai hasil struktur atau regularitas yang dapat diperkirakan dan berada di luar diri individu. Bersifat anti humanis karena mengesampingkan agen manusia dari inti penyelidikannya. Fenomena hanya memiliki makna ketika dikaitkan dengan struktur sistematis yang sumbernya bukan terletak pada individu. Pemahaman strukturalis terhadap kebudayaan memusatkan perhatian pada sistem relasi struktur yang mendasarinya (Baker, 2007).

Di sisi lain, dry leaf board merupakan produk material baru yang dihasilkan dari kegiatan eksperimen sebelumnya yang memanfaatkan sampah daun kering di perkotaan untuk dikonversikan menjadi material bangunan berupa papan. Bentuk papan dipilih berdasarkan pertimbangan fleksibilitas kemampuan dan kemudahan aplikasi pemanfaatannya. Kajian berikut ini akan berusaha menguraikan kondisi aktual dry leaf board dari cara pandang strukturalisme dengan cara mengidentifikasi sistem relasi pembentuknya di luar individu. Prosesnya berusaha menemukan makna dengan struktur sistematis yang bersumber pada dampak serta implementasi dari budaya yang melingkupinya. Dalam arti, metodologi strukturalisme akan digunakan untuk mengkaji sistem relasi struktur pembentuk dry leaf board seperti proses penciptaan, bentuk, dan aplikasi dry leaf board sebagai subjek kajian secara aktual.

Kesimpulan yang didapat diharapkan dapat menjadi acuan untuk pengembangan potensi bentuk dan fungsi dry leaf board dimasa yang akan datang. Selain itu, kajian ini diharapkan juga akan menghasilkan aspek-aspek esensial sebagai acuan untuk menjadikan dry leaf board sebagai salah satu produk material perancangan interior karya anak bangsa yang layak dibanggakan. Untuk itulah, peneliti memandang perlunya penelitian ini dilakukan.

\section{A. Rumusan dan Batasan Masalah}

Beberapa rumusan masalah yang dapat diangkat sebagai dasar pemikiran kegiatan penelitian ini, antara lain:

1. Dry leaf board adalah material baru yang berbentuk papan tetapi mempunyai karakter struktur yang berbeda dengan papan pada umumnya karena inovasi materialnya.

2. Sejauh ini belum ada kajian terkait eksistensi prinsip-prinsip strukturalisme dalam aplikasi perancangan bentuk dan produksi dry leaf board.

3. Pemaknaan dry leaf board masih mengacu pada visual bentuk dan kemampuan fisik, sementara latar belakang penciptaan dan produksinya sebagai obyek budaya masih belum banyak dipahami.

4. Masih adanya pemikiran bahwa gagasan strukturalisme merupakan cara pandang aplikasi linguistik saja dan belum mengarah pada konteks-konteks produk budaya lainnya. 


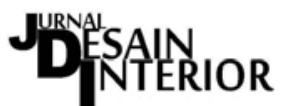

Vol. 2, No. 1, Juni 2017, pISSN 2527-2853, eISSN 2549-2985

\section{B. Tujuan}

Pembahasan kajian ini bertujuan untuk:

1. Mengungkap latar belakang penciptaan dan produksi dry leaf board untuk kemudian diidentifikasi melalui cara pandang strukturalisme sebagai karakter budaya secara aktual

2. Mengidentifikasi prinsip-prinsip universal dari pikiran manusia yang menjadi dasar karakter budaya dan kebiasaan-kebiasaan yang dilakukan manusia dikaitkan dengan kegiatan penciptaan dan produksi dry leaf board sebagai material perancangan interior.

3. Mengimplementasi cara pandang strukturalisme dengan memadukan nilai-nilai integral interdisipliner untuk pengembangan bentuk dan fungsi dry leaf board di masa yang akan datang.

4. Acuan peluang kegiatan pengembangan dry leaf board dengan melibatkan IKM terkait dengan pelaksanaan produksinya.

\section{METODOLOGI}

Kajian ini menggunakan pendekatan kualitatif dengan penekanan pada penalaran cara pandang strukturalisme terkait kegiatan analisis kondisi aktual dry leaf board. Seperti diketahui pendekatan kualitatif lebih bersifat praktis yang sangat terkait dengan kehidupan manusia sehari-hari. Pendekatan metodologinya lebih mengutamakan mengimplementasi gagasan strukturalisme untuk mengidentifikasi dasar karakter budaya dan kebiasaan-kebiasaan yang dilakukan manusia Indonesia dalam proses penciptaan dan produksi dry leaf board sebagai material perancangan interior. Pemikiran tersebut membuka peluang pembahasan integralistik unsur pembangun dari realitas gagasan dry leaf board, seperti: material, sambungan, kemampuan fisik, serta pola produksinya serta implementasi prinsip-prinsip strukturalisme dalam membangun sistem relasi bentuk dan struktur pada dry leaf board.

Kajian ini juga menggunakan metode analisis deskriptif untuk memaparkan dan menguraikan segala bentuk data yang diperoleh untuk dianalisa. Data-data yang dimaksud adalah yang berkaitan dengan pemahaman konsep strukturalisme serta sistem relasi bentuk dalam membangun integralistik struktur pada dry leaf board akan dianalisis untuk mendapatkan kesimpulan akhir.

\section{PEMBAHASAN DAN HASIL}

\section{A. Strukturalisme}

Strukturalisme lahir di Perancis pada tahun 1960-an dan berbasis pada karya Ferdinand de Saussure yang diorientasikan untuk memahami struktur-struktur yang mendasari bahasa. Basis teorinya berasal dari linguistik. Menurut aliran ini, setiap orang di masyarakat mengetahui bagaimana caranya menggunakan bahasa meskipun mereka tidak peduli akan aturan-aturan berkenaan dengan struktur bahasa. Menurut Simon Blackburn (2008), strukturalime adalah keyakinan bahwa fenomena kehidupan manusia yang tidak dimengerti kecuali melalui keterkaitan mereka. Hubungan ini merupakan struktur, dan latar belakang variasi lokal dalam fenomena yang muncul di permukaan ada hukum konstan dari budaya abstrak (Blackburn, 2008).

Strukturalisme menelusuri penggunaan bahasa berdasarkan prinsip-prinsip universal dari pikiran manusia yang menjadi dasar karakter budaya dan kebiasaan-kebiasaan yang dilakukan manusia (Haryanto, 2010). Di sini, bahasa manusia dilihat sebagai hasil rancangan dari 
pemikiran dan tindakan yang membentuk pola universal hingga menghasilkan realitas sosial. Dengan begitu strukturalisme menempatkan obyek budaya itu seperti literatur, arsitektur, dan seni yang harus dipahami dalam konteks-konteks yang lebih besar di mana mereka berada dan berkembang (Haryanto, 2010). Strukturalisme melihat makna sebagai hasil struktur atau regularitas, bersifat anti humanis dan berada di luar individu. Masyarakat dan kebudayaan dinilai memiliki suatu struktur yang sama dan tetap.

Riset dimanfaatkan sebagai cara untuk menyingkapkan struktur terdalam dari realitas obyek secara obyektif, ketat, dan berjarak (Sutrisno \& Putranto, 2005). Beberapa tokoh strukturalisme yang berpengaruh dalam penetapan spesifikasi struktur yang obyektif, ketat, dan berjarak, antara lain: Ferdinand de Saussure (Linguistik), Levi Strauss (Budaya masyarakat), Jean Piaget, L.S Vygotsky, dan Jacques Lacan (Psikologi), Frege, Hillbert (Metalogika dan metamatika), dan Michel Foucault (Filsafat-Poststrukturalisme). Tujuan strukturalisme adalah mencari struktur terdalam dari realitas yang beraneka ragam di permukaan secara ilmiah (obyektif, ketat, dan berjarak) (Sutrisno \& Putranto, 2005). Ciri-ciri itu bisa dilihat dari beberapa hal; hirarki, komponen atau unsur-unsur, terdapat metode, model teoritis yang jelas dan distingsi yang jelas. Ciri-ciri di atas dapat dilihat strukturnya:

1. Bahwa yang tidak beraturan hanya dipermukaan, namun sesugguhnya di balik itu terdapat sebuah mekanisme generatif yang kurang lebih konstan.

2. Mekanisme tersebut, selain bersifat konstan, juga terpola dan terorganisir, artinya terdapat blok-blok unsur yang dikombinasikan dan dipakai untuk menjelaskan yang dipermukaan.

3. Para peneliti menganggap obyektif, yaitu bisa menjaga jarak terhadap yang sebenarnya dalam penelitian mereka.

4. Pendekatan dengan memakai sifat bahasa, yaitu mengidentifikasi unsur-unsur yang bersesuaian untuk menyampaikan pesan. Seperti bahasa yang selalu terdapat unsur-unsur mikro untuk menandainya, salah satunya adalah bunyi atau cara pengucapan.

5. Strukturalisme dianggap melampaui humanisme karena cenderung mengurangi, mengabaikan, bahkan menugasi peran subyek (Sutrisno \& Putranto, 2005).

Strukturalisme menentang eksistensialisme dan fenomenologi yang dianggap terlalu individulistik dan kurang ilmiah. Salah satu yang terkenal adalah pandangan Maurice MarleauPonty yang menentang fenomenologi dan eksistensialisme tubuh manusia. Marleou-Ponty menekankan bahwa hal yang fundamental dalam identitas manusia adalah bahwa kita adalah obyek-obyek fisik yang masing-masing memiliki kedudukan yang berbeda-beda dan unik dalam ruang dan waktu (Magee, 2008).

\section{B. Dry Leaf Board}

Latar belakang penciptaan dry leaf board berasal dari pemikiran untuk memanfaatkan sampah daun kering yang banyak terdapat di perkotaan. Analisis dilakukan untuk mecari peluang pemanfaatan yang bersifat obyektif, umum, dan kolektif. Beberapa riset dan eksperimen perangkaian lembar daun kering dilakukan untuk mendapatkan hipotesa dan sintesa terbaik mengenai jenis produk yang akan dibuat. Kesimpulan awal yang didapatkan adalah daun kering akan dieksperimenkan sebagai material papan. Jenis material papan dipilih berdasarkan pertimbangan fleksibilitas, ruang lingkup pemanfaatan yang luas, kemudahan aplikasi, serta faktor masyarakat yang sudah terbiasa. Dengan mengacu pada asumsi di atas maka kegiatan produksi dilakukan, dan terciptalah dry leaf board.

Definisi dry leaf board adalah material berbentuk papan dengan tampilan permukaannya bertekstur daun kering. Untuk sementara ini, dry leaf board mempunyai ketebalan $18 \mathrm{~mm}$. Pemanfaatannya adalah sebagai material dalam kegiatan pelaksanaan perancangan interior 
dan elemen-elemennya. Gambar berikut merupakan tampilan bentuk dry leaf board untuk memperkuat deskripsinya.

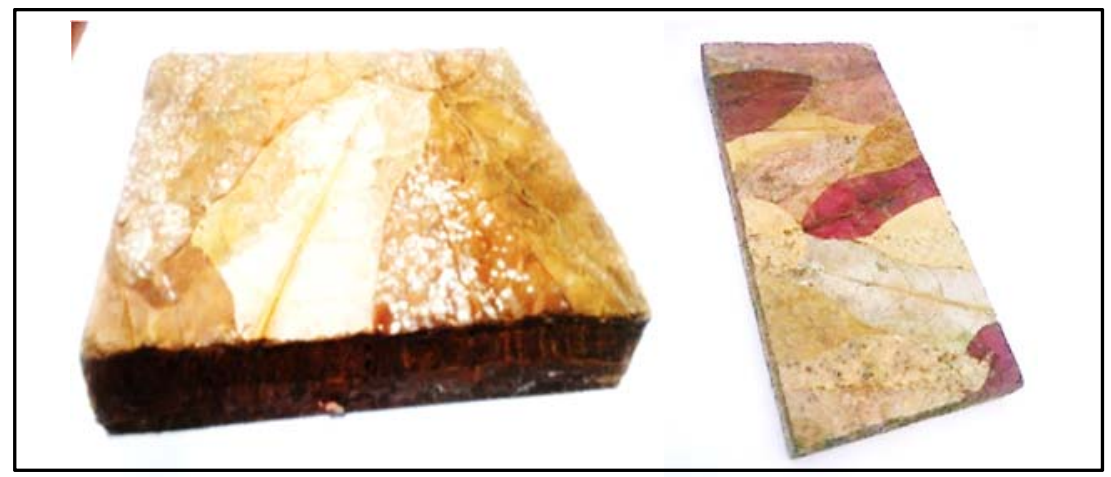

Gambar 1. Dry Leaf Board.

Sumber: Dokumentasi Penulis (2012)

Secara teknis, dry leaf board terdiri dari struktur dalam/inti yang dinamakan 'silang vertikal (vertical cross)' dan layer luar yang bertekstur daun kering. Struktur silang vertikal merupakan susunan daun kering yang dirangkai sedemikian rupa sehingga membentuk jaringan struktur dalam yang menjadikan dry leaf board kuat, rigid, berpori, dan keras. Setiap komponen unsur pembentuknya disatukan oleh lem dari jenis Chloroprene Contact Adhesive. Lem ini dipilih karena dapat menghasilkan daya rekat yang sangat kuat dan fleksibel. Hasil yang didapatkan adalah bentuk keseluruhan dry leaf board yang hampir setara dengan plywood dan multiboard. Beberapa keunggulan yang dimiliki dry leaf board yang tidak dimiliki material sejenis yang lain diantaranya tidak menghasilkan ampas pada saat digergaji, tahan air, tahan kelembaban, dan tidak berjamur. Sementara secara estetis, kualitas visual dry leaf board banyak ditentukan oleh penampilan tekstur lapisan permukaan luarnya yang terdiri dari rangkaian daun kering yang disusun secara horizontal sehingga membentuk lapisan/layer yang bertekstur dan bermotif daun kering. Penampilan teksturnya dinilai unik dan orisinil. Tekstur dan motif ini direncanakan dapat dimodifikasi sesuai dengan kebutuhan fungsi dan estetis.

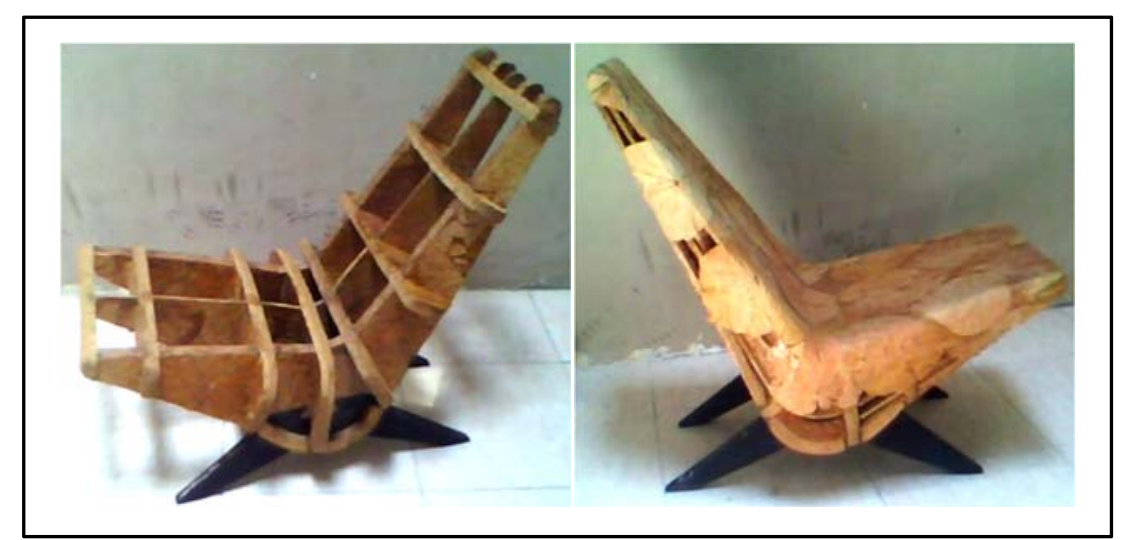

Gambar 2. Easy Chair dari Dry Leaf Board.

Sumber: Dokumentasi Penulis (2012)

Dengan kemampuan teknis dan estetisnya, dry leaf board diarahkan dapat berfungsi sebagai material perancangan elemen interior untuk produk-produk seperti: partisi, lapisan dinding, furniture, dan yang lainnya. Dengan penanganan desain dan aplikasi yang benar, 
terarah, serta konsisten, dry leaf board diharapkan akan mampu berfungsi sesuai dengan tujuan penciptaannya. Untuk itu, telah dilakukan dua penelitian untuk menguji coba dan membuka peluang fungsi dry leaf board sebagai material perancangan interior, yaitu sebagai struktur easy chair (2012) dan material akustik ruang hunian (2014). Hasil akhirnya pada Gambar 2.

Hasil penelitian menunjukkan bahwa pada level tertentu dry leaf board telah menunjukkan peran dan fungsinya dengan baik serta membutuhkan kegiatan pengembangan untuk menjadi lebih baik lagi. Dengan demikian, penelitian dan kajian di atas menunjukkan bahwa dry leaf board berpotensi memberikan kontribusi pada kegiatan perancangan produk yang berorientasi pada kemampuan strukturalnya yang ditunjang oleh bentuk dan karakter fisiknya. Dapat dikatakan bahwa dry leaf board mempunyai kemampuan yang setara dengan produk sejenis (multipleks, MDF, dan lain-lain) yang dihasilkan dari material berbeda, dalam hal ini kayu.

\section{Kajian Strukturalisme Mengenai Kondisi Aktual Keberadaan Dry Leaf Board}

Telah disebutkan diawal bahwa secara filosofis, dry leaf board membangun makna berdasarkan pada bentuk dan struktur tersebut yang terkait erat dengan pola pikir masyarakat dimana ia diciptakan. Dry leaf board merupakan suatu produk material papan yang dihasilkan dari pemikiran mengenai upaya-upaya untuk mengantisipasi isu-isu lingkungan hidup yang sedang berkembang dewasa ini. Mengurangi sampah kota, mengurangi ketergantungan terhadap bahan-bahan konvensional, memberdayakan masyarakat, serta penciptaan dan proses material yang ramah lingkungan menjadi acuan pembuatannya. Sebagai sebuah material alternatif, dry leaf board diupayakan dapat dimanfaatkan sebagaiman material papan sejenis yang sudah ada sebelumnya, seperti $M D F$, multipleks, plywood, dan sebagainya. Di luar faktor manusia sebagai sumber ide dan prosesnya, dry leaf board mempunyai aspek-aspek di dalamnya yang berperan penting dalam pembentukannya, antara lain: material, proses produksi, kemampuan fisik, serta hasil akhirnya. Masing-masing komponen merupakan hasil pemikiran dan pertimbangan manusia berdasarkan kondisi di luar individu manusia itu sendiri pada saat ini. Pemilihan material berdasarkan situasi terkini mengenai pemanfaatan dan nilai dari daun kering sebagai sampah kota. Proses produksi dry leaf board disesuaikan dengan karakter dan kemampuan daun kering. Kemampuan fisik dry leaf board merupakan hasil dari gagasan dan upaya strukturalnya. Sementara hasil akhir yaitu dry leaf board itu sendiri merupakan produk pengolahan daun kering terkini yang sudah layak dan siap diaplikasikan serta dipertanggungjawabkan.

Secara teoritis, strukturalisme adalah cara pandang yang berusaha mengungkap kondisi aktual suatu makna dengan mengesampingkan individu manusia melainkan lebih memusat pada sistem relasi bentuk aspek-aspek yang di dalamnya. Gagasan strukturalisme juga melakukan pencarian keterpaduan unsur pembangun dari realitas gagasan dry leaf board yang beraneka ragam di permukaan secara ilmiah (obyektif, ketat dan berjarak). Hal ini berlaku untuk semua pemaknaan secara global, termasuk juga pemaknaan dry leaf board. Dalam cara pandang strukturalisme, dry leaf board dapat dianggap sebagai sebuah makna yang tercipta dari sistem relasi bentuk komponen-komponen di dalamnya, seperti: material, proses produksi, kemampuan fisik, serta hasil akhirnya. Masing-masing komponen saling berinteraksi serta bersinergi untuk menghasilkan bentuk dan struktur dry leaf board seperti yang ada sekarang. 


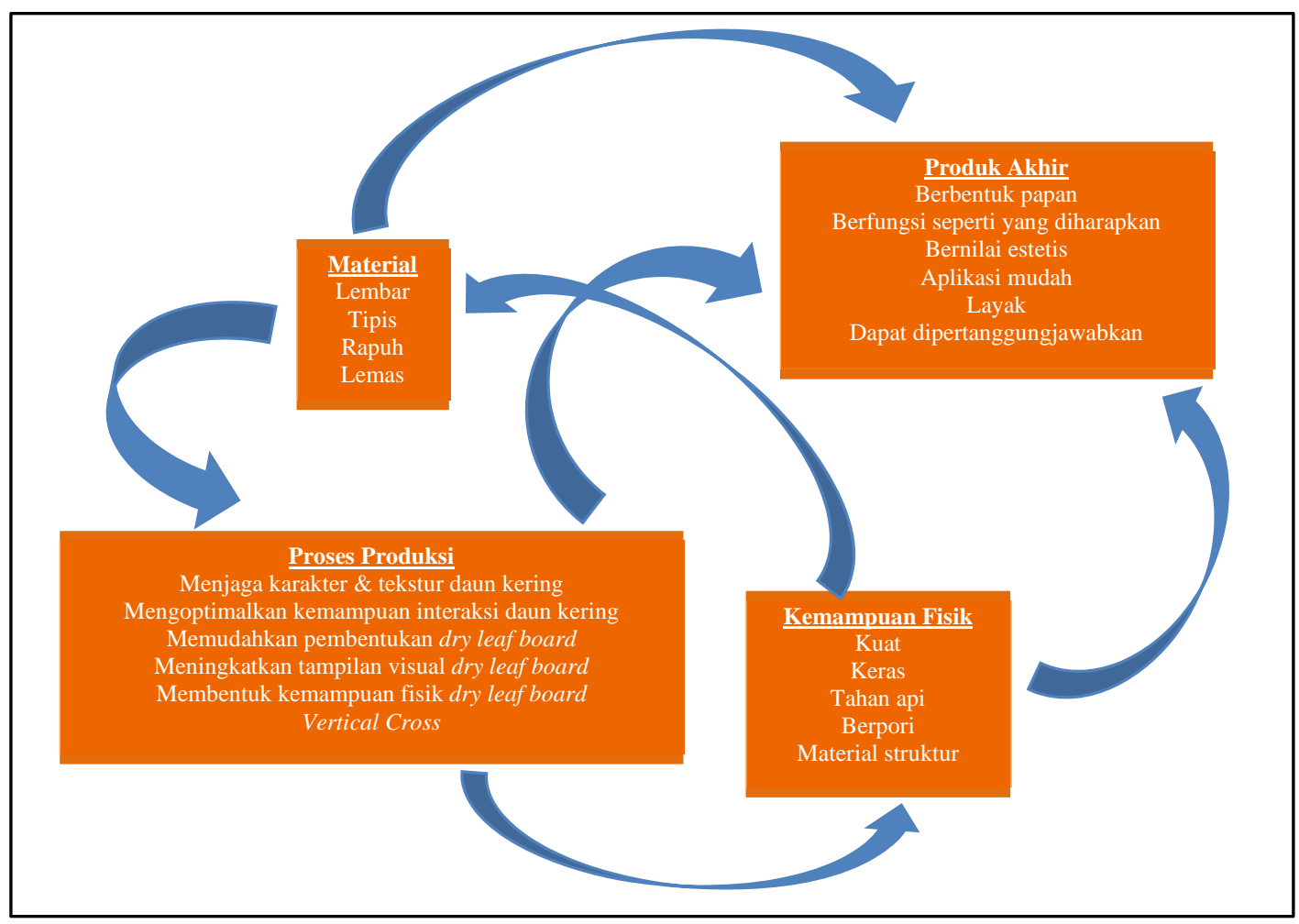

Gambar 3. Diagram Sistem Relasi Bentuk Dry Leaf Board.

Sumber: Konstruksi Penulis (2016)

Interaksi komponen material dengan proses produksi merupakan interaksi utama yang terlihat pada bentuk struktur dry leaf board. Komponen material menjadi dasar penentuan aplikasi perlakuan terhadap daun kering sebagai material utamanya. Karakter dan kecenderungan daun kering; bentuk lembar, tipis, rapuh, lemas; menghasilkan pemikiran mengenai pola perlakuan daun kering yang tepat untuk diimplementasikan pada proses produksi selanjutnya. Proses produksi dilaksanakan dengan maksud untuk menjaga karakter dan tekstur daun kering, mengoptimalkan kemampuan interaksi dengan material lain, memudahkan pembentukan dry leaf board, serta meningkatan penampilan visualnya. Proses produksi juga dilakukan dengan mengoptimalkan karakter daun kering untuk menghasilkan produk akhir dry leaf board. Produk akhir berupa papan yang dihasilkan diharapkan mampu berfungsi seperti yang diharapkan, bernilai estetis, layak, dapat dipertanggungjawabkan dan mudah diaplikasikan. Beberapa komponen produk akhir tidak lepas dari kemampuan fisik yang dimiliki dry leaf board yaitu kekuatan dan kekerasan dry leaf board yang dimiliki dari hasil proses produksi yang dilakukan sebelumnya. Kemudian kemampuan tahan terhadap api dan karakter struktur yang berpori. Gambar 3 merupakan sistem relasi bentuk dry leaf board yang menunjukkan korelasi masing-masing komponen yang dimilikinya.

Menurut Haryanto (2010) disebutkan bahwa strukturalisme menelusuri penggunaan bahasa berdasarkan prinsip-prinsip universal dari fikiran manusia yang menjadi dasar karakter budaya dan kebiasaan-kebiasaan yang dilakukan manusia. Melalui pembahasan sistem relasi bentuk di Gambar 3 menunjukkan bahwa kegiatan identifikasi kondisi aktual dry leaf board mengacu pada deskripsi prinsip-prinsip strukturalime tersebut. Diagram di Gambar 3 juga menunjukkan korelasi integral unsur-unsur pembangun kaidah-kaidah strukturalisme pada dry leaf board seperti material, proses produksi, kemampuan fisik, dan produk akhir dalam 
memberikan deskripsi mengenai kodisi aktual dry leaf board. Dengan begitu dapat diasumsikan bahwa prinsip strukturalisme dapat direpresentasikan dengan baik dalam kegiatan penciptaan dan produksi dry leaf board serta pemanfaatannya sebagai material perancangan interior.

\section{KESIMPULAN}

Secara bentuk dry leaf board adalah material berbentuk papan dengan tampilan permukaannya bertekstur daun kering. Dengan ketebalan $18 \mathrm{~mm}$, pemanfaatannya adalah sebagai material dalam kegiatan pelaksanaan perancangan interior dan elemen-elemennya. Dry leaf board dibentuk oleh beberapa pertimbangan yang dimaknai sebagai komponen pemikirannya antara lain material, proses produksi, kemampuan fisik, dan produk akhir.

Integralistik masing-masing komponen di atas merupakan implementasi prinsip-prinsip strukturalisme pada kegiatan penciptaan dan aplikasi dry leaf board. Melalui tahapan kajian yang bersifat ilmiah, rasional, dan obyektif telah menghasilkan produk dry leaf board yang layak dan dapat dipertanggungjawabkan.

Dengan kajian interdisiplin antar komponen di atas, cara pandang strukturalisme telah mampu menganalisis kondisi aktual dry leaf board untuk memperkaya estimasi solusi permasalahannya serta mereduksi segala sesuatu yang dapat menghambat kegiatan pengembangannya.

Satu lagi, gagasan strukturalisme juga mengungkap bahwa dry leaf board merupakan produk yang dihasilkan dari dinamika gejala budaya dan nilai-nilai kemanusiaan yang terjadi dalam masyarakat Indonesia. Dua aspek tersebut turut mempengaruhi proses pemanfaatan daun kering dan penciptaan dry leaf board. Alasan tersebut menghasilkan satu kesimpulan bahwa dry leaf board mempunyai nilai orisinalitas karakter budaya Indonesia yang layak dibanggakan serta dapat dimanfaatkan oleh lebih banyak masyarakat dari berbagai kalangan.

\section{DAFTAR PUSTAKA}

Barker, C. (2007). Cultural Studies. California USA: Sage Publication

Basuki, Undang Ahmad. 1992. Penuntun Praktikum, SISTEMATIK TUMBUHAN TINGGI. Bandung. Indonesia. Pusat Antar Universitas. ITB

Blackburn, S. (2008). Oxford Dictionary of Philosophy. United Kingdom: Oxford University Press.

Fisher, RA. 1971. Experiment Design, ${ }^{9 t h}$ Edition. Mac Millan publisher. London

Haryanto, S. (2010). Teori Strukturalisme : dalam Anatomi dan Perkembangan Ilmu Sosial. Yogyakarta: Bagong Suyanto dan M. Khusna Amal (ed) Aditya Media.

Hawari, Firman. 2012. 'Studi Faktor Kenyamanan Pada Kursi Santai Dengan Struktur Dari Material Dry Leaf Board’. Penelitian PNPB - ITS. Surabaya

Hawari, Firman. 2014. 'Kajian Dan Eksperimen Material Dry Leaf Board Sebagai Komponen Fungsi Teknis Dan Estetik Dari Sistem Akustik Ruang’. Penelitian PNPB - ITS. Surabaya

Haygreen, J.G; and JL. Bowyer. 1993. Hasil Hutan dan Ilmu Kayu (Suatu Pengantar). Diterjemahkan oleh Sutjipto A. Hadikusumo. Gadjah Mada University Press. Yogyakarta.

Magee, B. (2008). The Story of Philosophy. Yogyakarta: Kanisius.

Sutrisno, M., \& Putranto, H. (2005). Teori - Teori Kebudayaan. Yogyakarta: Kanisius.

T. Dick, George. 1971. Aesthetic, An Introduction. Pegasus Books. New York. USA 